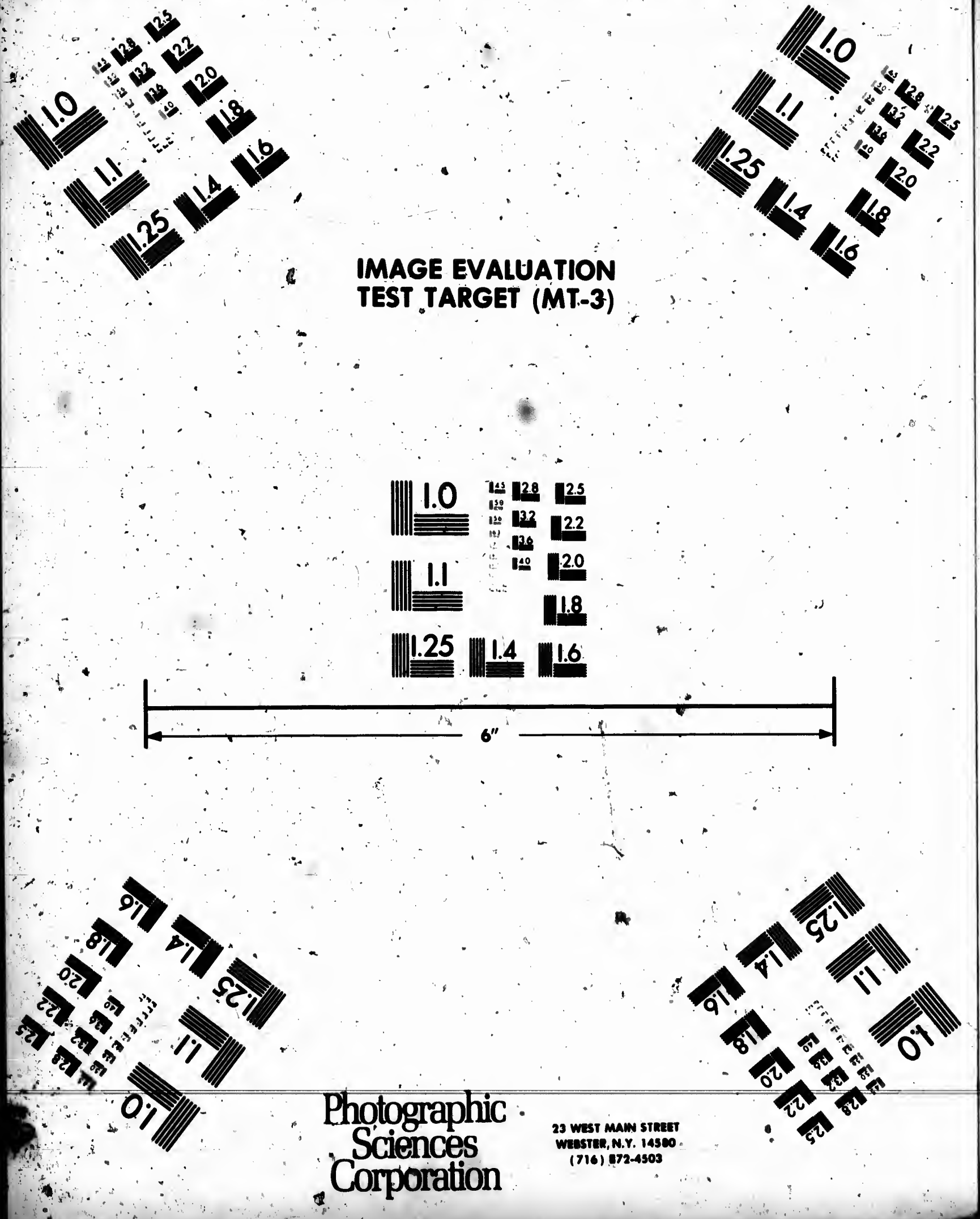




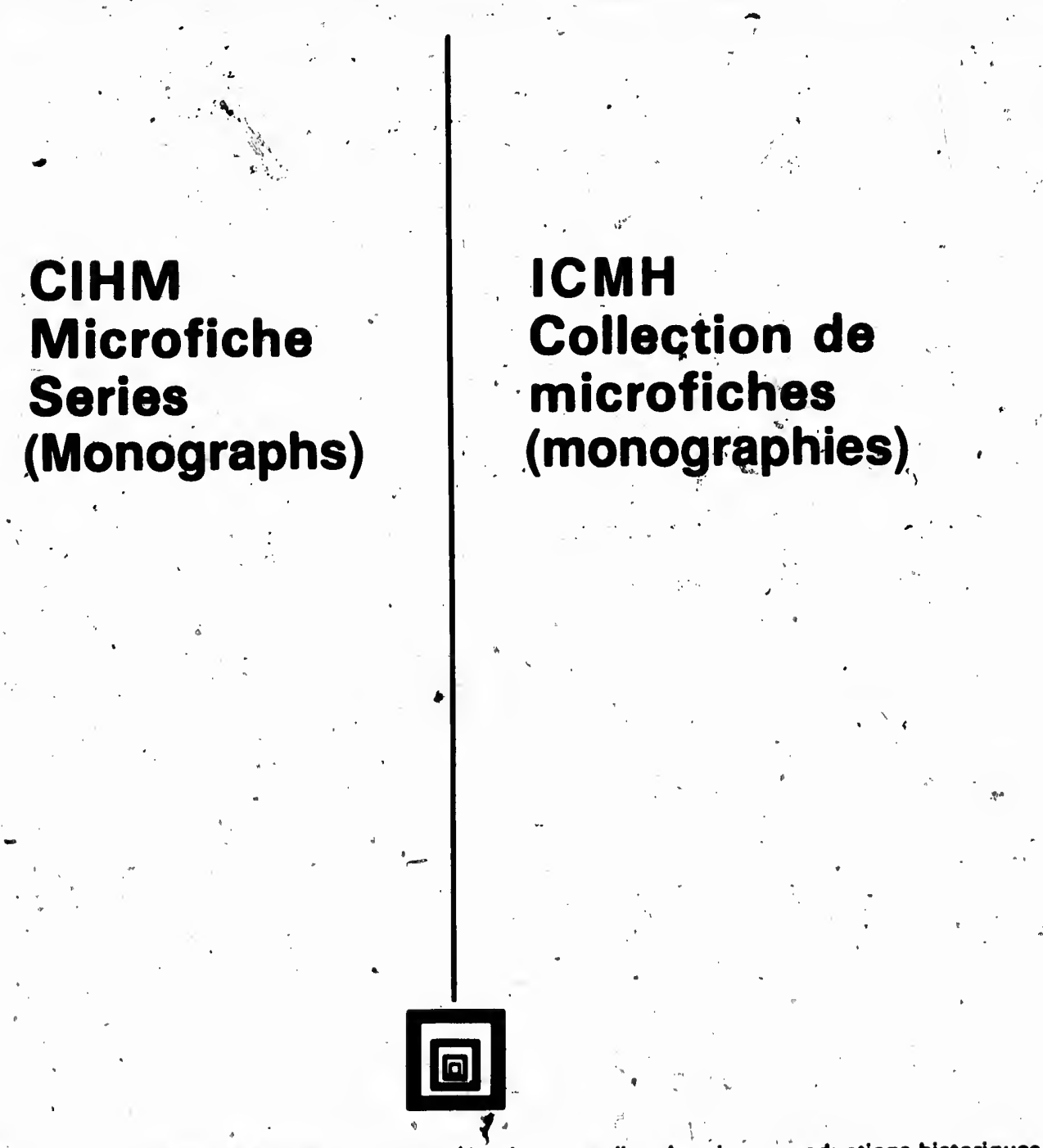

Canadien Institute for Historical Microreproductions / Institut canadien de microreproductions historiques 
The Institute hes attempted to obtain the best original copy available for filming. Festures of this copy which may be bibliogrephically unique, which mey alter any of the ifmaes in the reproduction, or which may significantly chanes the usual mothod of fllming, are . checked bolow.

Coloured covers/:

Couverture de couleur

Covers demajed/'

Couverture endommente"

Covers restored end/or ieminated/

Couverture restaurbet/ou pellieulce

Cover tith missing/

Le titre de couverture menque

Coloured mepel .

Cartis ghographiques en coulour

Coloured ink (i.e. other then blue of Beck)/

Encre de couleur (i.e. autre que blewe bu noire)

Coloured plotes and/or illustrations/

Plenches et/ou illustrations en coubur

Bound with other moterial/

Relib avec d'autres documents

Tipt binding may cause shadows or distortion along interior mergin/

Le reliure serrice peut causer de l'ombre ou de la distorsion lo long de la mares intérieure.

Blank leaves edded during restoretion mey sppeser within the text. Whenever possible, these have been omitted from filming/

II se peut que certioines pares blenches ajoutles lors d'une restauration epparaissent dens le texte. mais, lorsque cele dtait possible. ces fices niont pes étb filmies.
L'Institut o miecrofilmo lo mailleur exemplaire qu'il lui o ted posgible de se procurer. Les ditails de cet exemplaire qui sont peut fitre uniques du point de vue bibliogrephique, qui peuvent modifies uns imess " . reproduite. ou qui/peuvent exiper une modifiegtion dens lo mothode normele de filmew sont indiquis ci-densous.

\section{Coloured peres/}

Peeses decouleur

Paess demepedt

Paces endoinmestes

so.

Payes restored end/or demininted/.

Paces restaurís et/ou polliculces

Praps discoloured, stained of foxed/

Paces diciolories, techeties ou piquies

Ropes dotached/

Paeses ditachses

Showthrouch/

Trensparence

Quality of print veries/

Qualiti indanale de l'impression

Continuous pegination/

Pagination continue

Includes index(es)/

Comprend un (des) index

Title on header token from: /

Le titre de l'en-tlte provient:

Title page of issuel

Page de titre de lo livraigen

Caption of issuel

Titre de dlpart de la livraison

Masthead/

Gendrique (phriodiques) de la livraison

Additional comments:/

Commentaires supplímentaires:

This item is filmed ot the reduction ratio checked bolow/ Ce document est filmb ou taux do reduction indiqub ci-dessous.

$10 x$

$14 x$

$18 x$

$2 x$ $26 x$ $30 x$

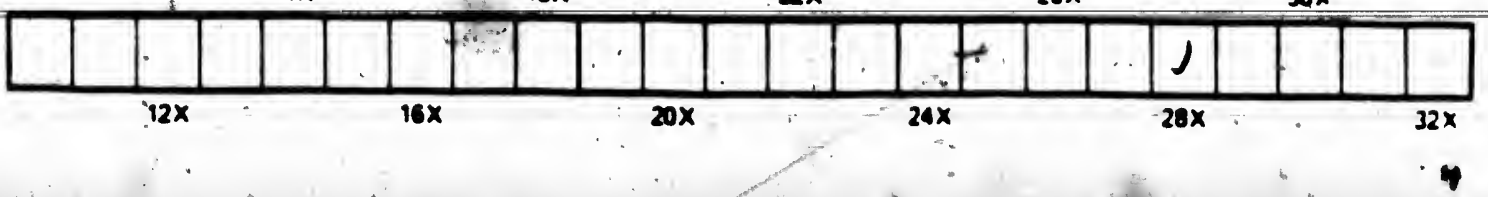


The eepy filmed hore hee been reproduced thenks the the eenerealey of:

$$
\begin{aligned}
& \text { Lbrery of the Nationd. } \\
& \text { Arehives of Cenche }
\end{aligned}
$$

The imagec oppearing here ore tho beot qualiky. poselble conoidering tho condiden and leglbillity of the original copy and in kecpling. whth the filming centraet epectificotions.

Original ceplee in printed poper ceviers are fllmed beginning with the frome cever end ending on the lief eses with a orinted or Illuotiveted impres. slon, or the beck cover when eppreportete. All other original ceples ers filmed bealining on the fires pase with a primted or Mustroted Impresclon. end ending or the last poes with a orinted or Ulustrated impresalon.

The leat recorded treme on each microfiche shall coneain the oymbel $\rightarrow$ Imeaning "CON. TINUED"). pr the aymbol $\nabla$ (meaning "END"). whichever epplice.

Mape, plates. Charts. ote. mar be Alimed ot differeme reduction retios. These too lisires to be entirely included in one exposeure are fllmed beginning in tho uppor. lote hand corner, bet to right and top to bottom, se many framee as regulred. The following dlegrams Ullustrate the mothod:

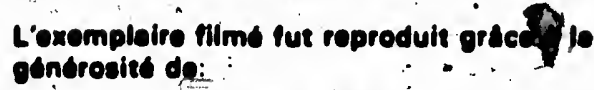

Lb bibliothique des Archives notionales du Canads

Les imeged sulventes ont cis roproduites evec to plus árand soin. compre tenu de la centition et de is notrote de t'oxpmplaire filmo. or en contermits ovec los condlitions du contrat de fflmọo:

Les exemplalres erigineux dont le cbuverture on papier cet imprimbe cont IIImbe on commencent - per la promier plat or en terminant sois par la dernibe pece qul comporte une emproines: d'impreadion ou d'illustration, soit par le second plas, ecton ib eas. Tous les autres exemplaires

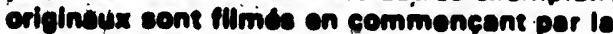
premicre pees quil comporte une emprainte d'Impresien ou dillustrotion of en perminent par la derriltre pege qui comporte une tolle emprointe.

Un des symboles sublente apparaitre sur la dernibre imoge de eheque mieroflehe. selon lo ces: 10 symbole $\longrightarrow$ signiflo "A sUIVAE". I6 eymbole $\nabla$ sionifie "FIN".

Lè cartes, plonehos, tableoux, cte. pouvent itre" filmes des toux de reduction difforionts. Loreque b documont est trop erond pour otro

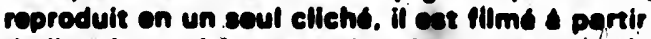
de liengle eupsribur eouche. do eouche droite. ot di have on bas. on prenant b hombre d'images nscesaire. Les diboremmes suivents Illustrent in mothode.
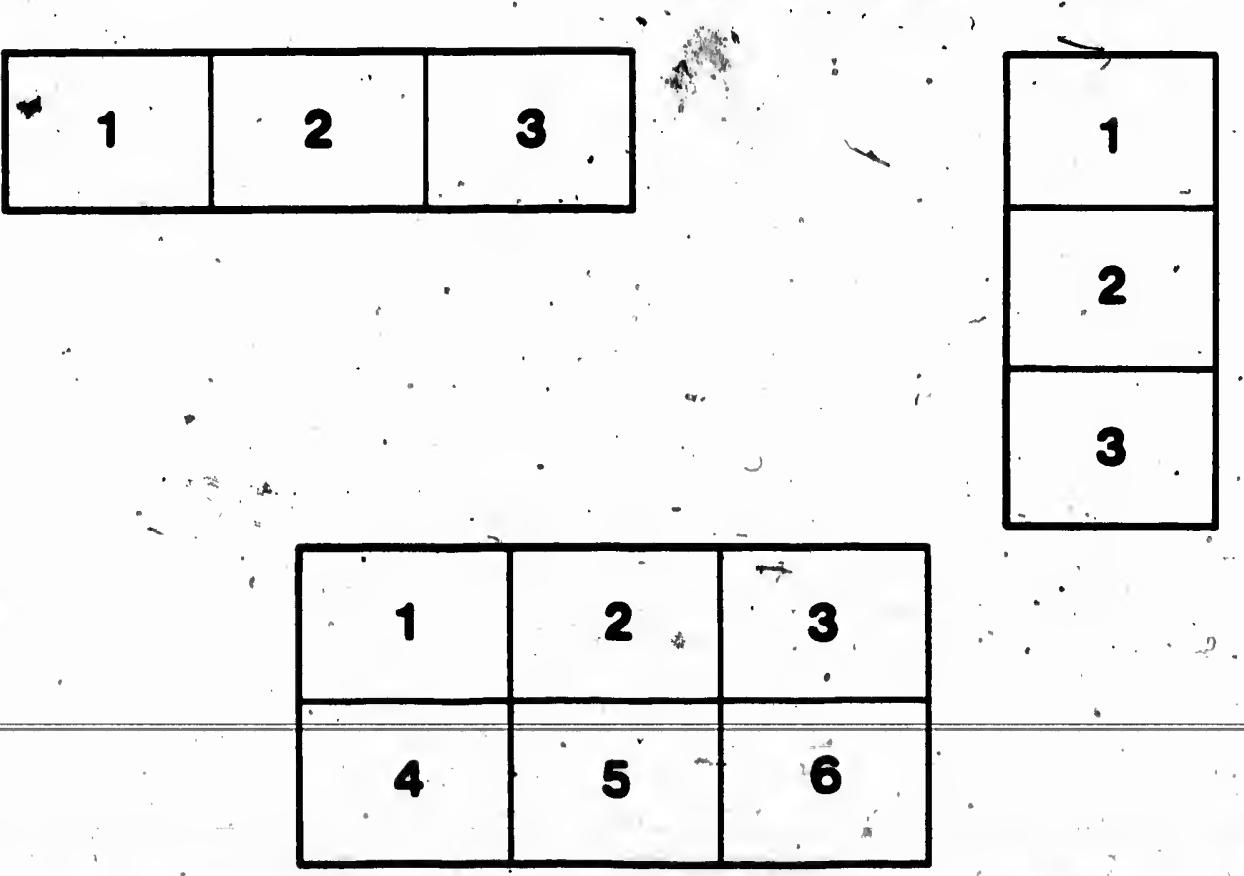


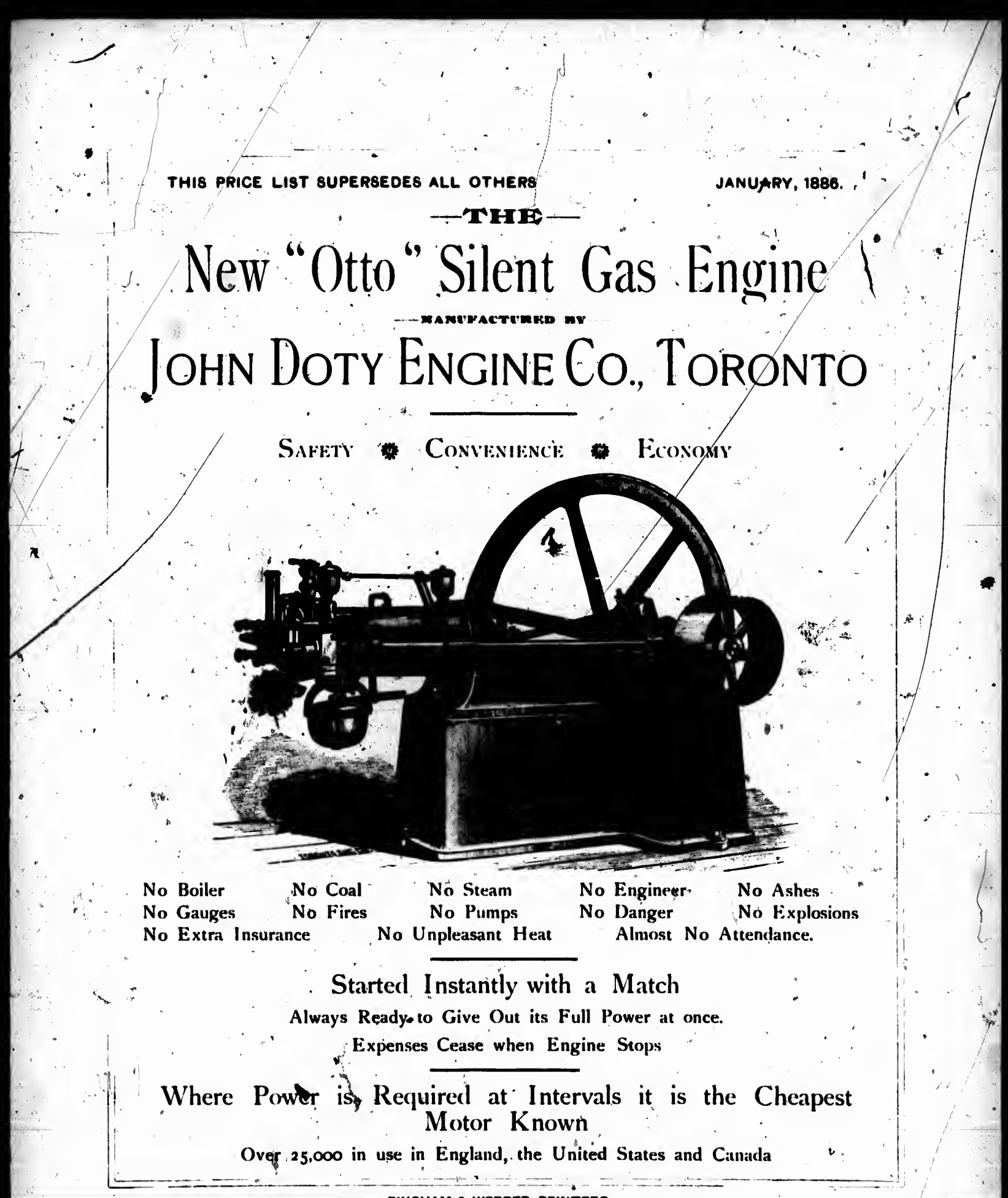




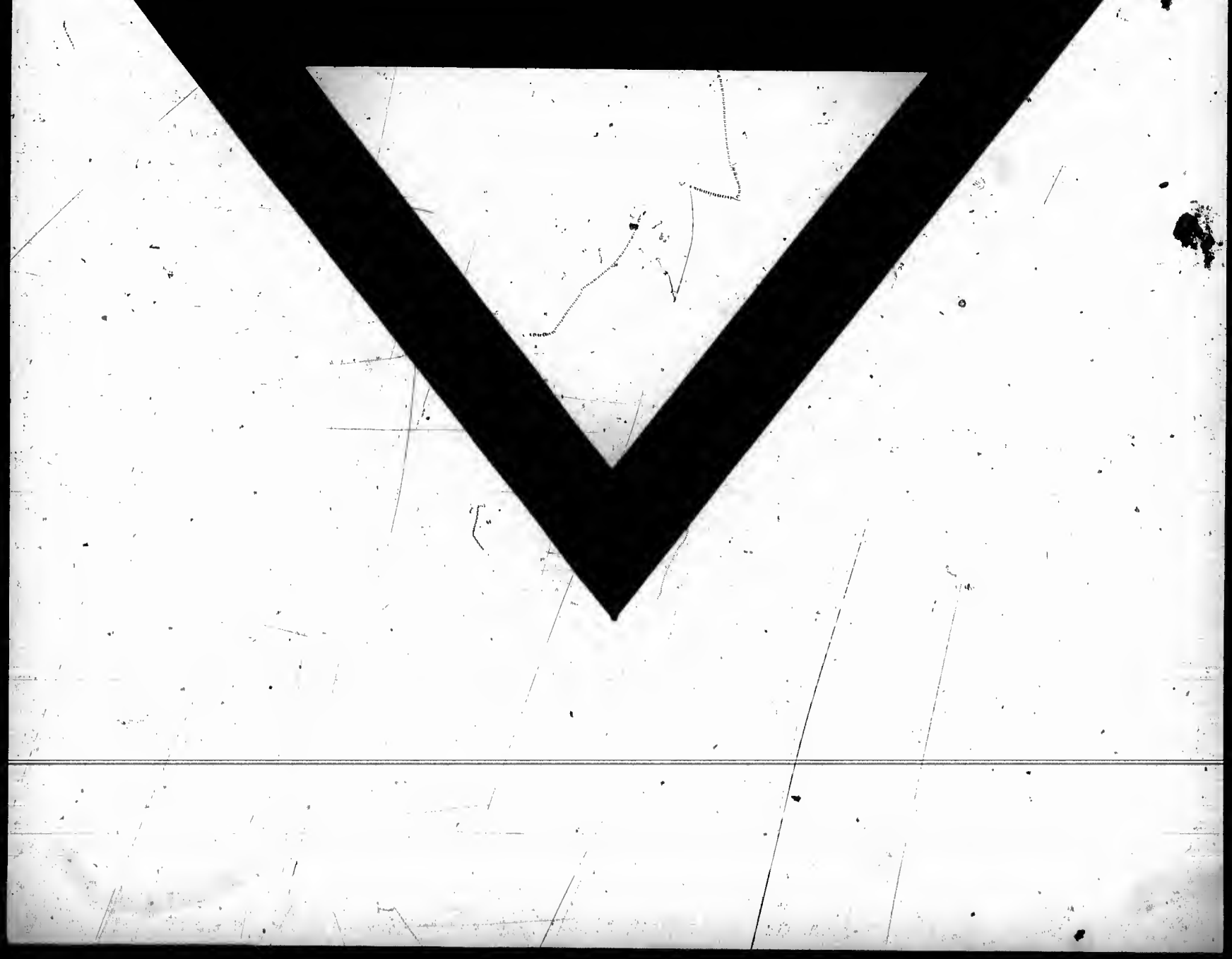




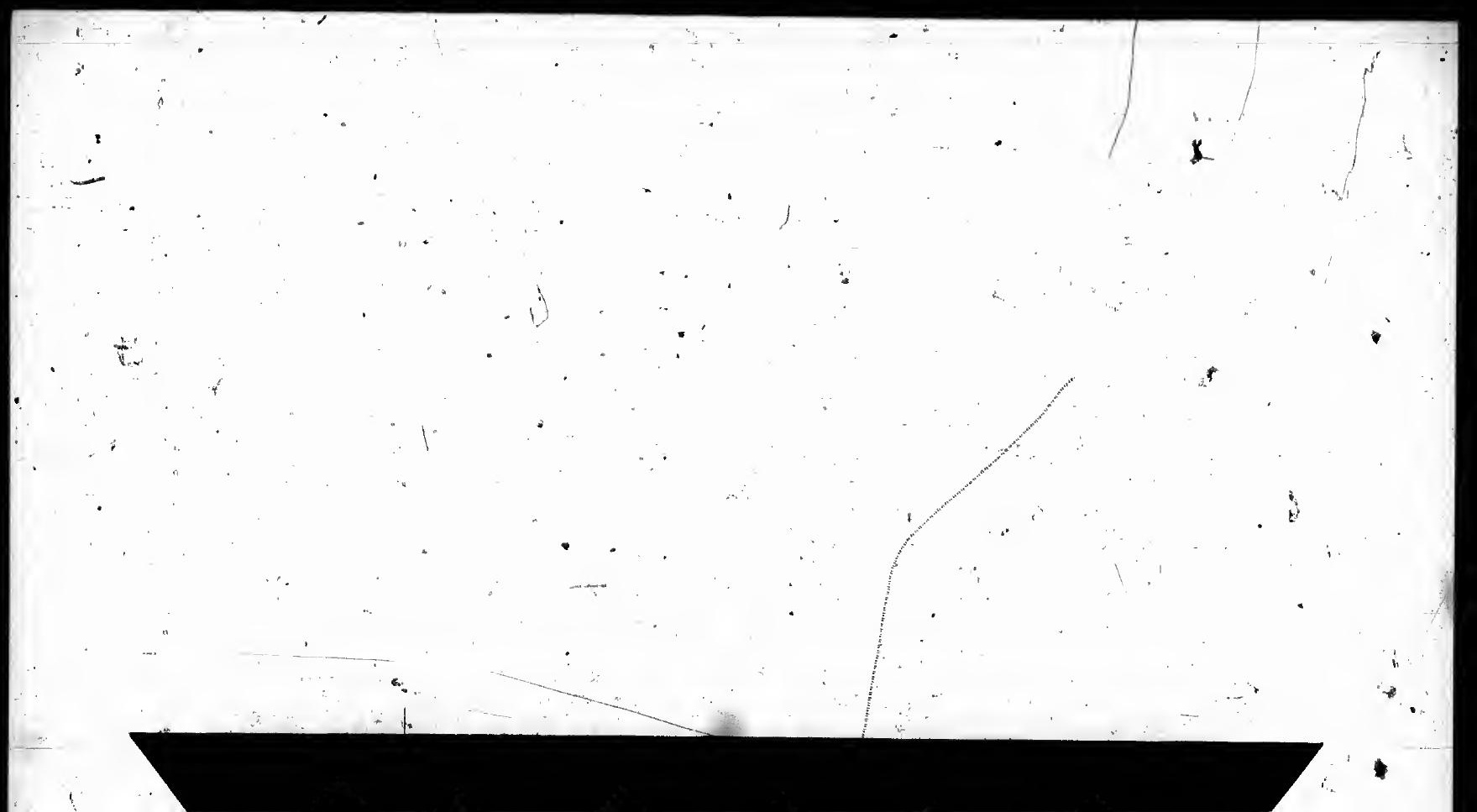


b.

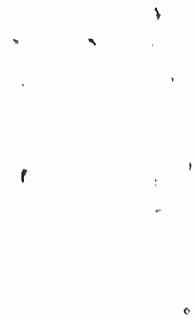

-

3

n 